are with good reason shocked at the way our foodstuffs are transported and handled. They also find other causes for criticism, though happily there is much they can admire, and even perhaps a little they might copy, more especially in the way of administration. Yet only the other day, in Liverpool, a distinguished American hygienist commented unfavourably, and it is to be feared justly, on the appearance of a crowd congregated in the streets of that great city. He saw there signs of destitution and drink, which it would not have been easy to match in any similar gathering in the United States. Here is evidence of failure and food for thought.
The students of the school must be so trained and guided that they will acquire the wider outlook. They must be versed in the elements of sociology, they must become apostles of the doctrine of co-ordination and consolidation of social effort in all its ramifications, and there must be impressed upon them the significance of what has been called the " anticipatory work" of the epidemiologist. It will be well if they and their preceptors bear constantly in mind the truth of Hermann Biggs's dictum, which Dr. Sprott of Tasmania recently quoted to such good effect: "To make the unfit fit is a noble task, but to make the fit fitter is a larger and higher achievement."

\title{
OPHTHALMIO PRACTICE.
}

\author{
N. BISHOP HARMAN, M.A., M.B.CANTAB., F.R.C.S.ENG.,
}

SENIOR OPHTHALMiC SURGroN, WEST LONDON HOSPITAL; LECTURER IN OPHTHALMOLOGY (LATE DEAN), WeST LONDON POST-GRADUATE COLLEGE.

The Educational Number of the British Medical Journal is, for the most part, of interest to prospective medical students, or their parents, guardians, or teachers. For these the store of information furnished therein regarding medical schools, medical degrees, and medical appointments is as the map that guides the stranger who essays an entry into a new land. To these this article on ophthalmic practice will make small appeal. It is written mainly for those who have already explored the land in some directions and staked out some claim to prospect therein. To two sets of men these observations upon ophthalmic work may be of value: first, to the man who proposes to take up ophthalmology as his life work as an ophthalmic surgeon; and secondly, to the man who proposes to enter general practice, or may even now be in general practice, and who desires at the same time to make himself proficient in some special branch of medicine and surgery, and whose inclination turns towards eye work. For both of these types of men there is a steadily increasing field for work, and the work itself is particularly fascinating and satisfying.

\section{The Field for Work.}

Within the last score of years the demand for qualified practitioners competent to deal with ophthalmic work has increased greatly. The first great move promoting this demand was brought about by the establishment of the medical inspection of school children. Indeed, it may be said with much truth that it was the work of ophthalmic surgeons amongst school children that created the demand for the medical inspection and treatment of school children. Now, little more than twenty years since the inauguration of this work, there are throughout the country medical men and women habitually investigating the problems iff errors of refraction and diseases of the eye, and doing this work in a fashion that is a credit to themselves and the service to which they are attached, and to real advantage to the school children who are their patients. There is a repercussion from this systematic work amongst school children upon the general public. Parents are learning that what they thought good enough for themselves is not good enough for their children. The casual choice of glasses from the counter of any spectacle vendor, or the more mystifying supply of glasses from a prescribing optician, the parents now know is not good enough for their children, and they are beginning to wonder if these casual methods are good enough for themselves. Hence there is arising a steadily increasing demand for the provision of an ophthalmic benefit for the million, and through it the possibility of obtaining the services of medical practitioners competent in ophthalmic work when need arises. The demand is based upom the ever-inereasing complexity and strain of a highly organized civilization. Statutory authorities, shipping and ralway controller's, monufacturers and other employers, are bound to select fit persons for their particular work, and eye fitness is a primary necessity. Workers in every walk of life, teachers, scriveners, artisans, seamstresses, and mothers, each in turn feel tho need to remove a possible handicap arising from defective eyesight, or from conditions of sight ill adapted to the work in hand.
The intimate relation of the conditions of the eyes to general bodily health and disease makes it inevitable that this demand can only be satisfied by the provision of fully qualified medical practitioners. Any lesser provision would prove an expensive substitute in the long run. These are the new fields for eye work now being added to the existing forms of ophthalmic practice, and they may ultimately prove to be the wider fields.

\section{The Work.}

There is perhaps no form of practice furnishing such a variety of experience as eye work, and it is certain there is no huppier field of work for those whose minds desire something like completeness in their work. The examination of each eye patient is a royage of discovery. The sorting methods of the receiving-room of an out-patient department of a hospital have no place with eye patients. The wiser the doctor the less inclined is he to satisfy the dramatic instinct for a " lightning diagnosis" based upon the patient's statement of complaint. He learns to value scientific methods and to use them. But scientific methods of inquiry alone will not satisfy; they must lead to something, and in eye conditions we have this requirement, for there is so large a mastery over means that the end is obtained with a frequency and a completeness that is a source of gratification to both patient and doctor.

\section{The Young Graduate.}

The roung graduate in medicine may well take stock of his equipment. He has worked diligently during the years of his novitiate, passed his qualifying examination with credit, and perhaps held a house appointment at his hospital. During these six years he will have learned something of the anatomy and physiology of the eyes, and of their neural and vascular connexions; he will have attended the eve clinic for the prescribed period and a few lectures and demonstrations on the diseases of the eyes. He will have learned that a " pink eye" may be due to conjunctivitis, an iritis, or a glaucoma, and possibly be able to give a fair account of the means whereby the necessary distinction is to be made in any given case. But in the absence of that assurance, born of habit, he knows that the next time he sees a red eye facing him he will feel hopelessly confused by the minuteness of the symptoms, even though he has been assured that they are writ large for him to read with his own eyes. He knows what an ophthalmosccpe is, and has made a valorous effort to master that "open sesame" to vascular and cerebral conditions. Indeed, once he got such a view into the interior of an eye that he ventured to pronounce (with some hint of reservation) that the eve was normal, for which daring he rectived high commendation from his preceptor in that he had recognized a " normal fundus oculi." But alas! three weeks later, on his return: from a jolly holiday, he found he had forgotten the magic: words, and by no means could he peep again through that, chink in the human anatomy which revealed such wonders. The memory annoys him now, and it is aggravated by tho recollection of the assurance of the eye surgeon, who, when called into the wards by his neurologist or physician 
colleagues to examine a hard case for them, saw things and wrote them down as definite statements of fact that had the determining influence in clearing up the knotty diagnosis. Or he remembers another case of obscure headache or of wryneck which had baffled physician and surgeon, and which the ophthalmic surgeon claimed as his own proper case, for the symptoms were due, he said, to an undetected defect of muscle balance, a hyperphoria, or latent vertical squint, which being corrected by glasses gave the patient immediate and permanent relief. These and other such cases are impressed upon his mind, and he feels a very proper greed for the mastery of that power for himself. He cannot buy it, he must win it. And now, just as he is going out from the house of learning after half a dozen years he wonders how he is to get it.

First let me sketch out a course of work for the would-bo ophthalmologist, and next indicate the manner in which the general practitioner may render himself reasonably competent in eye work.

\section{The Young Opirthalmologist.}

The young ophthalmologist has before him a strenuous course of preparation, one which will absorb some three years before he can expect to be able to settle himself in the practice of his specialty and hope to obtain the suffrages of the practitioners of his chosen area of work. He must be so well reported of to them as to secure their initial attention, and so well equipped for his work as to he able to retain and increase what he obtains by report.

He will need to attach himself to an eye hospital of good standing, where there is plenty of work and a good teaching staff, or, failing that, to the eye department of a large general hospital, again preferably a teaching hospital. His former teachers will furnish him with introductions to the school and possibly to some member of the staff. There he will learn the everyday practice of his chosen work. He will find ample, often superabundant, clinical material for investigation. But unless he is content to become little more than a rule-of-thumb worker, a mere copyist of other men's methods (and a poor copyist, since he may not know the sources of their inspiration), he will not be content with absorption in clinical work. He will take out a course in optics, wrestle with the complexities of mathematical and applied optics; he will proceed to learn how lenses are made, and even to know something of the making of the instruments he uses and the spectacles he proposes to order. He will take out courses on the physiology of the eye, become familiar with the intricacies of muscles and muscle movements; and also in neurology, and learn to think in nerve paths, so that at least he will be able to meet the neurologist in his own house. If time allows he will work at a nerve hospital and perhaps hold a house office there. He will make friends with the clinical pathologist and carry off from him as much as he is able to bear. At his chosen eye hospital there will be work in the bacteriological laboratory, and he should constitute himself liaison officer between the clinician and bacteriologist, so as to see both ends of the lines of communication and be able to judge of their significance. Again, he will work in the pathological laboratory and learn the technique of the preparation and examination of excised eyes and pathological material. In all these things he should strive to put himself in such a position of practical knowledge that he could if needs be do the work himself; for it may be that his lot will be cast in a place where a multiplicity of skilled workers is not available, so that if he is to continue in scientific methods or carry out research for himself he must have the assured knowledge that will enable him to set others to work.

As a corrective to this intensive study of disease he will do well to get out into the world and see what the average man, woman, and child is like. Let him make friends with the school medical officer, visit the schools, do some of the medical inspection himself, go to the clinics and take a hand in the work; let bim visit the several types of special schools-for the blind, the myopes, for the sufferers from contagious eye diseases, for the deaf, the cripple, the mentally defective-and the open-air schools for the weakly, and let him observe the special features of each. Let him go round with the factory surgeon and see the inside of the works whence come the injured eyes. Let him by hook or by crook see the inside of every sort and condition of human activity where work and lighting are likely to have any .effect upon the eyes. Lastly, his holidays must be wholly devoted to the exploration of new fields of eye work, to visits abroad to Continental and, if possible, American clinics, so that his mind may receive the enlargement of other men's methods.

During all this period he will read assiduously, first from advanced textbooks and then from original papers, and gradually he will find that some one or other branch of the work will seize upon his imagination, so that his daytime clinical and practical work will be turned to special account in the investigation of some problem, and he will find himself a research worker. Examinations will need to be considered, and these should be got over early as a necessary evil. $\mathrm{He}$ will need the Fellowship of the College of Surgeons of the chosen area of his work; or if he proposes to work in the dominions one or other of these Fellowships or a diploma in ophthalmology will serve his turn. He will have served as clinical assistant or chief clinical assistant or as a house officer in the eye hospital or department, and these also will serve as vouchers to his credit when he seeks to obtain a hospital appointment.

\section{The General Practitioner and Eye Work.}

The programme of the general practitioner who wishes to secure a reasonable competence in eye work will be much less ambitious. He can give but months where the other man must give years. But if he is intent upon his effort and is prepared to make the necessary sacrifice of his leisure and of some of his general practice, he can secure his end; for others have done it before him. He will be wise, at any rate at first, to confine his effort to a mastery of the diagnosis and treatment of the ordinary disorders and diseases of the eye. For his purpose he must become thoroughly familiar with the use of illumination, corneal loupes, and retinoscopy mirror, and the ophthalmoscope. A real working knowledge of these instruments based upon his prolonged training in general medicine will make him a reasonably competent worker in ophthalmology, who may be trusted to carry on the work of a school clinic and investigate and treat the ordinary run of private eye cases. These limitations need not bound his vision, for I have known men in general practice who were able to diagnose accurately a complicated defect of muscle balance.

The man in general practice should, if he could, get a clear three months' course at an eye hospital or postgraduate college where " refresher courses" are provided. If he cannot do that he should attach himself to the eye clinic nearest his home, and arrange to attend there regularly at definite hours. It may be he can only find a school clinic near enough, but that will do. If he can show the worker in the clinic that he is in earnest, that he will attend on the stated days and regularly-no matter at what cost to himself-he will find that the doctor in charge of the clinio will welcome him as a colleague and show him all the treasures of his clinic; but for the casual dropper-in no one will have any use, or count him other than a hindrance to work-a nuisance.

Work of this order to be effective should be carried out on a system, combining practice with reading. It is well to confine the work at the clinic at each visit to the working out of one case only. A patient of intelligence should be chosen, and every mode of examination known to the worker carried through methodically. Every step should bo recorded in his private case-book, and each difficulty experienced and fact observed noted therein. At the close of the work his experienced colleague will go over this record with him, and later at his home he will compare his observations with the statements of his textbooks. If he will work in this slow and methodical way he will make steady advances in the mastery of his work, and, better still, ho will know the reason for what he is doing. It is only through such a process of observation and thought that he can arrive at that maturity of judgement which knows how to apply the ascertained fact to the life and habits of each patient, and so achieve the treatment of the patient and not of mere symptoms. 